doi: $10.19090 / \mathrm{i} .2021 .32 .83-99$

UDC: $339(497) " 04 / 14 "$

ISTRAŽIVANJA

JOURNAL OF HISTORICAL RESEARCHES

$32(2021)$
ORIGINAL SCIENTIFIC PAPER

Received: 30 April 2021

Accepted: 6 July 2021

\author{
DEJANA VASIĆ \\ University of East Sarajevo, Faculty of Philosophy Pale \\ dejana.vasin@ffuis.edu.ba \\ SNEŽANA BOŽANIĆ \\ University of Novi Sad, Faculty of Philosophy \\ snezana.bozanic@ff.uns.ac.rs
}

\title{
MEDIEVAL MERCHANTS ON THE ROUTE BETWEEN THE DALMATIAN (RAGUSAN) LITTORAL AND THE CITIES ON THE SOUTHERN HUNGARIAN BORDER: IMPACT OF TRADE ON MOVEMENT
}

\begin{abstract}
The inhabitants of Dubrovnik played an important role in the development of longdistance trade not only in the Balkans, but in other places as well. The cities along the southern Hungarian border were also within the scope of Dubrovnik's merchants, and thanks to their activities in this area, trade flourished between the Dubrovnik (Ragusan) littoral and the lower Sava and Danube regions. From the fourteenth century onwards, these merchants played a crucial role in the development of trade in these areas and most trade was conducted through them. They supplied the cities along the lower Sava and the Danube Rivers with a variety of goods, but most often dealt in cloth. This was particularly apparent during the Despotate, when Belgrade and Smederevo were developed cities full of wealthy nobles who dressed in fine fabrics imported from Dubrovnik. Dubrovnik's merchants long dominated trade in these areas. However, the arrival of the Ottomans and the wars they waged in the lower Sava and Danube regions often caused considerable damage to their commercial endeavors.
\end{abstract}

Keywords: Dubrovnik's merchants, trade, Sava and Danube regions, cloth, Middle Ages.

I $\mathrm{n}$ the late Middle Ages, trade was a highly developed economic sector. There were two types: local and long-distance. The purpose of local trade was to fulfill local populations' basic demands for food and finished products. Long-distance trade, however, which developed out of the need to transport goods from distant areas, was a more advanced type of trade since it included a professional merchant who acted as a middleman between the manufacturer and the consumer. The inhabitants of Dubrovnik played an important role in the development of long-distance trade not only on the Balkans, but in other places as well. By the twelfth century, Dubrovnik's burgeoning maritime trade had positioned it as a significant commercial center. At the same time, the inhabitants of 
Dubrovnik were also establishing trade routes in the hinterland. Dubrovnik's trade reached its zenith between the thirteenth and fifteenth centuries when the mining industry in the Serbian state was flourishing. This economic branch created significant connections these two societies and provided them with mutual benefits. ${ }^{1}$ At that time, many people from Dubrovnik traveled to Serbia to conduct business in almost all of the major economic centers. $^{2}$

\section{Trade links between the Dalmatian (Ragusan) littoral and the cities along the southern Hungarian border}

The cities along Hungary's southern border were also in the scope of Dubrovnik's commercial interests, and trade there flourished thanks to their activities in this area. They also established colonies there according to their needs. They settled first in Mitrovica, then in Kovin and Belgrade, and finally in Smederevo. They were also present in other places further afield such as Ilok. Their presence in these regions dates to as early as the thirteenth century. ${ }^{3}$

\subsection{Mitrovica}

Dubrovnik's first significant colony in this area was established in Mitrovica. They were first mentioned in 1296 in Sirmia ulterior and again in 1302 in Sirmia citerior. ${ }^{4}$ They were mentioned in Mitrovica specifically in 1306.5 In the first decades of the fourteenth century, some members of the Rastić (Resti), Petranja (Petrana) and Ranjina (Ragnina) aristocratic families resided there, as did many others from Dubrovnik. ${ }^{6}$

By the mid-fourteenth century, the colony in Mitrovica had grown considerably. Members of the Menčetić (Mence), ${ }^{7}$ Kašica (Casica), ${ }^{8}$ Pucić (Poca), ${ }^{9}$ and Petranja (Petrana) families ${ }^{10}$ from Dubrovnik were mentioned as residing and conducting business exclusively in Mitrovica. One of the frequently mentioned members of Dubrovnik's colony in Mitrovica was Nikola Herpa (Nicola Cherpa), ${ }^{11}$ but there were many commoners as well. ${ }^{12}$

In the years following, Dubrovnik's settlement in Mitrovica grew increasingly larger. Konstantin Jireček notes that it peaked between 1356 and 1396, and he mentions the trading privileges that had been granted to Dubrovnik's merchants in Mitrovica. Dubrovnik's

\footnotetext{
Jireček 1915: 104; Rokai 1995: 38-42; Lučić 1976: 103-112; Tadić 1968: 519-529; Novaković 2005: 132 136, 147-152; Ćirković 1997: 48-50; Tadić 1971: 20-36; Božić 1949: 43-44; Krekić 1957: 4-8.

2 Dubrovnik's settlements in Bosnia and Serbia: Ćuk 1992: 85-94; Kovačević-Kojić 2007: 491; Dinić 2003b: 455-469; Id. 2003c: 669-679; Hrabak 1953: 91-102; Id. 1984(b): 5-87.

Dinić 1958: 13.

Gelcich 1897: 26-27; Čremošnik 1932: 64-165; Hrabak 1980: 57.

Tkalčić 1879: 45; Gelcich 1897: 212; Hrabak 1980: 57; Manken 1960: 385, 427.

Tkalčić 1789: 24, 45; Dinić-Knežević 1986: 13-14; Hrabak 2006: 100-101; Id. 1980: 57.

Tkalčić 1879: 103.

Gelcich 1987: 143; Manken 1960: 172.

Dinić-Knežević 1986: 16; Manken 1960: 368

Dinić-Knežević 1986: 15; Jireček, Radonić 198: 190; Dinić-Knežević 1979: 89-90.

Manken 1960: 177-178; Dinić-Knežević 1986: 15; Hrabak 1984b: 20-21.

Rački 1882: 43-44; Dinić-Knežević 1979: 90; Id. 1986: 16.
} 
recognition of Hungarian supremacy in 1358 only deepened and improved the connections these Dubrovnik merchants had already established there. ${ }^{13}$ Members of the Menčetić (Mence),${ }^{14}$ Gučetić (Goce) ${ }^{15}$ Sorkočević (Sorgo), Gundulić (Gondola), Lukarević (Lucari), ${ }^{16}$ Bunić (Bona), ${ }^{17}$ and Katena (Catena) ${ }^{18}$ families were still there, as were some commoners. ${ }^{19}$

From the 1370s on, commoners were mentioned more frequently in Mitrovica, and some even died there. ${ }^{20}$ In January 1388 , Herve de More, (Cherve de More) a commoner, was elected consul of Mitrovica because there were no noblemen living there at the time. ${ }^{21}$ The lack of aristocratic families in this period might have led to a decrease in trade between Dubrovnik and Mitrovica. However, during this time the biggest trading partnership in Hungary was established, ${ }^{22}$ and the colony in Mitrovica flourished. ${ }^{23}$

After the Battle of Nicopolis, the Ottoman army invaded Srem and Slavonia, overrunning Mitrovica along the way. The inhabitants were forcibly displaced, Dubrovnik's merchants abandoned Mitrovica, and their government forbade from returning. When Mitrovica recovered from the Ottoman devastation, people from Dubrovnik began coming to the city again, but this was reduced to individual cases. At this point, people from Dubrovnik focused more on Belgrade, although some who were in Belgrade also conducted business in Mitrovica. ${ }^{24}$ In all likelihood, Dubrovnik's colony in Mitrovica did not completely disappear nor did Dubrovnik's merchants stop coming and conducting business. But over time, other destinations became more attractive.

Shortly after the Ottoman overran Mitrovica, the government of Dubrovnik inquired about its citizens who had settled in Hungary. In December 1369, envoys were sent to Ilok and from there to Buda, accompanied by another fellow citizen, which supports the claim that the inhabitants of Mitrovica had indeed moved to Ilok after the disaster. In the years following, merchants moved more of their business to Ilok, which caused disputes among them and resulted in their government convening judicial councils to resolve them. ${ }^{25}$ By 1412, there were many people from Dubrovnik living in Ilok, as was demonstrated by around twenty names appearing in records during this short time. ${ }^{26}$

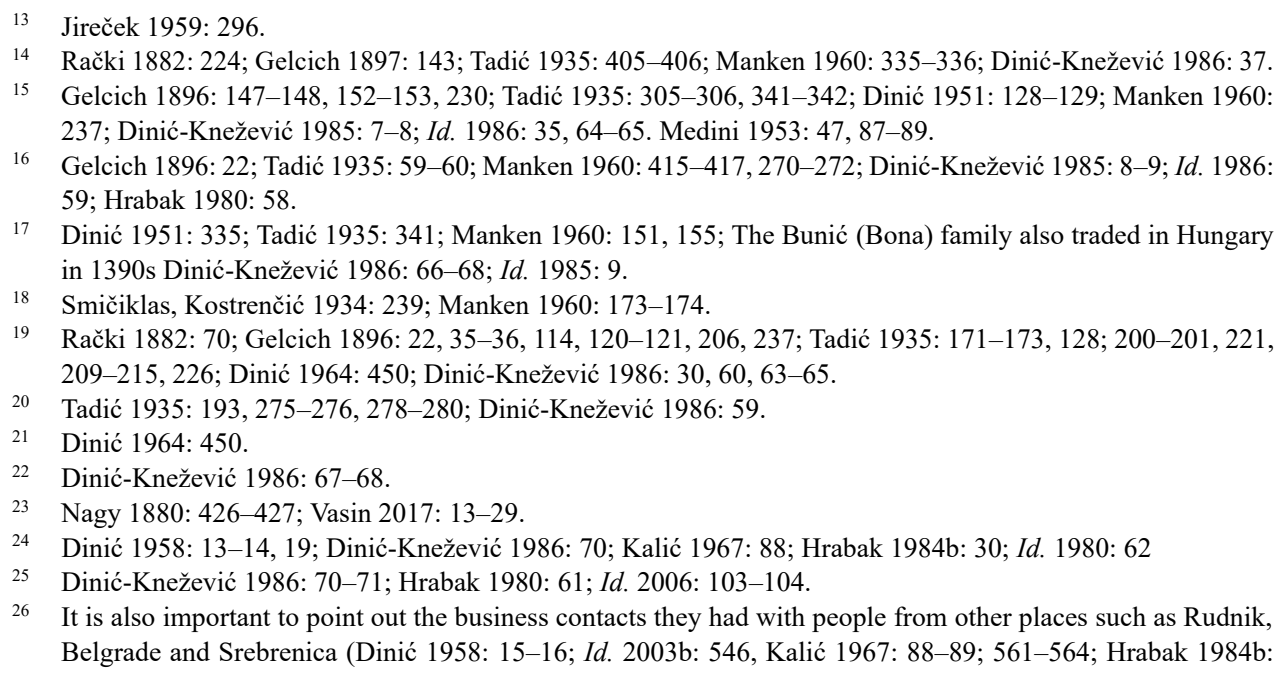




\subsection{Kovin}

The decrease in trade in Mitrovica sparked the interest of Dubrovnik's merchants in Kovin. In 1361 and 1362, they were mentioned in connection with some disputes in which they suffered losses, but at that time their government did not offer much protection, which may also be evidence that not many of them were present then. ${ }^{27}$ Additional information from 1377 shows people from Dubrovnik were present in Kovin in the fourteenth century. ${ }^{28}$ Prosperous trade in Kovin began to emerge the end of the fourteenth century. In an attempt to strengthen Hungary's defenses, King Sigismund encouraged the development of border towns. ${ }^{29}$ According to Ilarion Ruvarac, King Sigismund issued a privilege charter to Kovin in January 1396. He referenced earlier privileges granted to the city and exempted its inhabitants from paying taxes throughout Hungary. ${ }^{30}$ By the end of the fourteenth century, Kovin had developed into a significant commercial settlement where a salt chamber was located and where the thirtieth (a Hungarian tax on foreign trade), was collected. ${ }^{31}$

It is therefore not surprising that after the devastation of Mitrovica, Dubrovnik's merchants reoriented toward Kovin. We have information about their legal disputes dating from the beginning of the fifteenth century. Judicial councils were convened on June 17 and July 18, 1409, and records from them mention at least fifteen merchants who were living Kovin then, but there were undoubtedly many more. ${ }^{32}$ In March and May of 1410, judicial councils were also convened there. In total, four representatives of the aristocracy and 22 23 commoners were listed in these disputes, but there mostly likely were more of them. ${ }^{33}$ There were probably merchants from Dubrovnik in Kovin throughout this period in varying numbers, but consuls and the judges were named on January 18, 1430 for the first time since 1412. During these years, the župans of Kovin county alternated between the Talovac brothers, Matko and Franko. The government in Dubrovnik contacted Matko Talovac several times with requests for him to come to the defense of their traders. ${ }^{34}$

Ottoman raids into southern Banat created unfavorable conditions for Kovin's further economic growth. In February 1438, King Albert stepped in to protect his subjects. Kovin's hardships continued after the siege of Smederevo in 1439, when the Ottomans crossed the Danube twice and also sacked Kovin, taking many of its inhabitants as slaves.

30-31); People from Dubrovnik were also living in Ilok. They primarily traded with their countrymen from Srebrenica, as well as those in Belgrade and Smederevo. (Hrabak 1980: 61; Dinić 1958: 45-46, 56-57; DinićKnežević 1979: 92).

27 Tadić 1935: 42-43; Smičiklas 1915: 201-202; Ćirković 1970: 82-84; Dinić-Knežević 1986: 70.

28 Tadić 1935: 351-352; Ćirković 1970: 84-85.

29 Magdics 1888: 5.

30 Ruvarac 1934: 423-424; Ivánfi 1872: 160-161; Rokai 1969: 92; King Sigismund's charter, issued on November 29, 1428 in Karansebes, gave Kovin considerable privileges, a practice continued by other Hungarian kings as well. (Magdics 1888: 1-4; Vitković 1887: 1-5; Dinić-Knežević 1988: 26).

31 Rokai 1983: 141, 160; Dinić-Knežević 1988: 25.

32 Dinić 1958: 15; Hrabak 1980: 60; Id. 2006: 102-103.

33 Some of these people from Dubrovnik traded in nearby places as well, and they traded with their partners from the surrounding cities such as Smederevo, Belgrade, Rudnik, and Novo Brdo. (Dinić 1958: 29; Hrabak 1980: 60; Id. 1984b: 30 Kalić 1970: 56-57).

34 Dinić-Knežević 1986: 174-175. 
Those who survived and escaped slavery left Kovin and fled to Buda. ${ }^{35}$ Kovin on the lower Danube recovered only after the Crusade of Varna, but it failed to attain its previous glory. ${ }^{36}$

It seems there were still citizens of Dubrovnik living in Kovin during this period. A envoy from Dubrovnik contacted his government on November 6, 1454 from Kovin, but after 1458, there was no further mention of them there. ${ }^{37}$ However, Dubrovnik's colony in Kovin was not particularly large, especially in comparison with the one in the neighboring Smederevo. Smederevo experienced its heyday in the period after the restoration of the Despotate when Kovin was already in decline.

\subsection{Belgrade}

At the time Kovin was developing economically, the burgeoning commercial trade in Belgrade was beginning to slow. Despot Stefan Lazarević wanted to expand it into a large, developed city, so he sought to encourage both his subjects and people from outside the Despotate to settle in Belgrade by granting privileges. ${ }^{38}$ People from Dubrovnik also had a colony there, although based on the number of disputes recorded there, it appears they were not numerous. However, they did not start doing business in Belgrade at this time. They just continued and expanded what they were already involved in. Thus, there were merchants in Belgrade who, alone or with their partners, conducted business in Srebrenica, Novo Brdo, Trepča, Priština, Janjevo, Rudnik, Zajača, Valjevo, Smederevo, and Rudište, as well as in Kovin, Mitrovica, and Saros. Some of them stayed in Belgrade for several years, and some even died there. ${ }^{39}$ During the reign of Despot Stefan, the Dubrovnik colony was most likely quite small. This is indicated by the small number of judicial councils and by around ten names of noble families - which is indeed not many, even when considering not much material from this period has been preserved. It was probably necessary for some time to pass before the city could develop and establish itself as a trading center according Despot Stefan's plans. By the time Despot Đurađ returned Belgrade to King Sigismund, trade had already been developing there for the past twenty years, and. King Sigismund sought to continue the process. He invited Dubrovnik merchants to continue coming to Belgrade and trading there. They accepted the invitation and in the years following became considerably more active in the area. ${ }^{40}$ Some of them continued the business they had started during the reign of Despot Stefan. ${ }^{41}$

In the period from when Belgrade was returned to King Sigismund until the city was besieged in 1440, the Dubrovnik colony grew to around 90 members, of which

35 Magdics 1888: 19-25, 32-34, 36-37; Ruvarac 1934: 429-432; Ludaić 1862: 57-58; Vitković 1887: 13-14, 22-44; Dinić-Knežević 1988: 28; Ćirković 1994: 320; Kubinyi 1990: 141-142.

36 Teleki 1853: 243-244; Kalić 1967: 121-122; Radonić 1905: 261-262; Kubinyi 1990: 140-145; Magdics, 1888: 25-32; Vitković 1887: 15-23; Dinić-Knežević 1988: 29; Ludaić 1862: 58-59.

Dinić-Knežević 1986: 176.

Konstantin Filozof 1936: 86; Kalić 1967: 84-85; Mladenović 2007: 347; Kalić 2009: 189-198

Dinić 1958: 14-16, 17-19, 26-28; Kalić 1970: 56-58; Hrabak 1953: 99-100; Manken 1960: 272, 277-285; Dinić 2003b: 517,561, 570, 683; Hrabak 1984b: 32-36.

40 Dinić 1958: 20-21; Kisić, Božanić 2012: 191-192.

41 These included Vuk Mihaila Bobaljević, (Babailo) brothers Matko and Franko Talovac, and many others. (Dinić 1958: 18-19, 23-26, 29, 36; Krekić 1956: 118; Dinić-Knežević 1985: 9-12; Kolarević: 1975: 101-112; Kalić 1967: 106-109, 112, 272-274, 296; Thallóczy, Áldásy 1907: 86-93, 104-106, 111-123, 124-126, 134-135). 
approximately 73 were commoners and 15 belonged to the nobility. ${ }^{42}$ It should be noted that these were only those who had been involved in disputes, and that the actual number was likely much higher. They remained in Belgrade for several years. The members of the nobility came from the families Bobaljević (Babalio), ${ }^{43}$ Gučetić (Goce), ${ }^{44}$ and Gundulić (Gondola). ${ }^{45}$ Commoners had established commercial ties in Belgrade as well, and some of them even stayed in Belgrade for several years. ${ }^{46}$

Difficult times for the city's development came after the first Siege of Belgrade in 1440. According to the sources, only a small number of people from Dubrovnik continued conducting business in Belgrade during these difficult times. ${ }^{47}$ During that time, not a single council was convened to resolve legal disputes. At the time of the first fall of the Despotate, in total there were only around twenty people from Dubrovnik mentioned in Belgrade. This is a significantly smaller number in comparison to the preceding period, but this period was shorter. It is also noticeable that the nobility was no longer present. ${ }^{48}$ All of this seems to indicate that, at the time of the first fall of the Despotate, trade in Belgrade for the people from Dubrovnik more or less continued but had already begun to decline.

After the Long Campaign and relations with the sultan had been somewhat settled, trade was restored in Belgrade. Some people who had been there previously stayed on. ${ }^{49} \mathrm{New}$ merchants emerged, ${ }^{50}$ but members of Dubrovnik's nobility were almost gone. Altogether, there were only around fifteen names connected to Belgrade during this period until the city was besieged in 1456. Only a few judicial councils were convened, and in some cases the authorities in Dubrovnik did not even know where their citizens were and ended up convening councils in several places. ${ }^{51}$ It seems that the merchants no longer stayed in one place for long, which could be an indication of ongoing uncertainty and, most likely, poor business prospects.

The Siege of Belgrade in 1456 brought an end to the city's economic development. The city was razed, and the population was ravaged by plague. Smederevo fell three years later, and the Ottomans seized the whole of the Despotate, leaving Belgrade on the border with an extremely hostile country. Under such conditions, it was difficult to engage in commerce without interruption, although Dubrovnik merchants continued to conduct business in Belgrade. Commoners took over almost all of the work. The only nobleman who visited Belgrade was Natal Sorkočević (Sorgo), although he was more connected to Smederevo. ${ }^{52}$ That there were only twenty people from Dubrovnik mentioned in Belgrade after 1456, demonstrates unequivocally their commercial decline there. ${ }^{53}$ It can be

\footnotetext{
42 These numbers are only approximate due to the nature of the sources. (Dinić 1958: passim; Kalić 1967: 294). Dinić 1958: 25-28, 44, 45. 
confirmed that some of them had done business in the city before. Others were mentioned for the first time, although this does not necessarily mean they had not already been there. ${ }^{54}$ There are cases which suggest commercial activity did continue to some extent despite the difficult economic environment in the areas conquered by the Ottomans. ${ }^{55}$

A decline in the involvement of Dubrovnik's merchants was especially striking starting in the $1480 \mathrm{~s}$. Not a single nobleman was mentioned nor were any judicial councils, and only a few documents related to commerce confirm this. Everything indicates that, after the siege of the city in 1456, commerce in Belgrade was in a state of ongoing decline. Dubrovnik's merchants were coming less often and was reduced to individual cases, without any participation from the nobility. It was only after Belgrade came under Ottoman rule that the Dubrovnik settlement there began a slow recovery. ${ }^{56}$

\subsection{Smederevo}

Of the towns mentioned on the Sava and the Danube, Smederevo was the last to begin developing. Dubrovnik's merchants had been coming Smederevo since the reign of Despot Stefan. They had come from Belgrade, where at the time economic development was being encouraged.$^{57}$ In 1411 three judicial councils were convened, along with another in 1412, which is certainly not indicative of an area undergoing rapid economic expansion. Dubrovnik's merchants' visits to Smederevo were rare and sporadic. This is illustrated by the fact that new judicial councils were not convened for more than twenty years after those previously mentioned. ${ }^{58}$ Even when the Smederevo Fortress was built as the capital city during the reign of Despot Đurađ, it did not immediately attract a large number of merchants from Dubrovnik. ${ }^{59}$ The data from the judicial councils indicate that there were five of them in the city in 1436 and nine in 1438. None were mentioned in Smederevo when the Despotate first fell. ${ }^{60}$ It is also important to point out that, in this period, the mining towns of Srebrenica, Novo Brdo, Trepča, Rudnik and Priština were much more appealing for Dubrovnik's merchants, and there were more of them there than in Smederevo. ${ }^{61}$ Some of them came to Smederevo from Belgrade. ${ }^{62}$ It appears that Dubrovnik's merchants did engage in some trade in the new capital, but Belgrade, which at the time was at its commercial peak, continued to be an important waystation for them in the region.

After the Despotate was restored, the number of Dubrovnik's merchants in Smederevo began to rise. Commerce was revived, and they developed more ties to the city. According to data from the judicial councils, from 1445 to 1458 there were 347 members of their colony, but

Ibid. 72,81 .

Ibid. 91-92; Hrabak 1980: 64.

56 Hrabak 1966: 29-41; Id. 1984a: 12-16, 33-35; Id. 1969: 36-38; Id. 2006: 111-112; Miljković-Bojanić 2004:

104-105, 128-132; Tričković 1992: 101; Evlija Čelebi 1979: 88, 93.

Dinić 1958: 13-14.

Kovačević-Kojić 1970: 103.

Ćirković 1970: 64.

Kovačević-Kojić 1970:104.

Spremić 1994: 690-698.

Dinić 1958: 38-39, 44-45, 49, 54; Kovačević-Kojić 1970: 106. 
there certainly were more of them because this only includes those involved in legal disputes. ${ }^{63}$

Smederevo attracted merchants from developed centers such as Priština, Novo Brdo, Rudnik, and Trepča, and by 1449 it had the largest number of people from Dubrovnik. ${ }^{64}$ Unlike the other towns, Smederevo was in the far north of the country and was therefore the most protected. So it is not surprising that, when fleeing the Ottomans, the Dubrovnik merchants chose Smederevo as their next destination.

A large part of the Dubrovnik colony in Smederevo consisted of the nobility. They were present in the city up until the fall of the Despotate and made up around one-third of the Dubrovnik population in the Serbian capital. They were mostly appointed as consuls and judges. Commoners in Smederevo were rarely chosen to serve in these positions, with the exception of one named Nikola Radulinović, who was appointed consul. ${ }^{65}$ Most nobles in Smederevo were from the Sorkočević (Sorgo) family, ${ }^{66}$ and after them were members of the Crijević (Zrieva), ${ }^{67}$ Gučetić (Goce ${ }^{68}$, Đorđić (Georgio) ${ }^{69}$, Bunić (Bona) ${ }^{70}$, Menčetić (Mence) $^{71}$, Rastić (Resti) ${ }^{72}$, and Gradić (Grade) ${ }^{73}$ families, among others.

Due to the precarious military situation and Ottoman advancements in the Balkans, the number of people from Dubrovnik in the capital began a steady decline starting in 1454, although they still traded there. When Smederevo was besieged in 1456, there were only about a dozen of them, judging by the council records, but by 1458 , there was no more mention of them..$^{74}$ In the years that followed, they engaged in trade sporadically. Up until the 1460s only a few councils were convened, and from 1465 to 1485 there was not a single mention of them in Smederevo, which was certainly related to military conflict in the area. After hostilities ceased, they were more frequently mentioned either as traveling merchants or permanent residents. At the beginning of the sixteenth century, they branched out and expanded their commercial activities. ${ }^{75}$

63 Of the 347 members of the Dubrovnik community, 210 of them only appeared once, while the others remained in the Despot's capital for several years, and some of them for 9, 10, or even 13 years, which shows us that they were not just passing through this city and they had strong ties to Smederevo. (Kovačević-Kojić 1970: 106).

64 Kovačević-Kojić 1970: 110; Hrabak 1984b: 29-51.

65 Kovačević-Kojić 1970: 111,116; Jireček, Radonić 1981: 370.

66 Manken 1960: 419; Spremić 1994: 38, 75-77, 80, 219, 255, 299, 314, 375,413, 415, 593, 605, 614, 631-632, 641, 644, 648, 654-655; Dinić 2003c: 675-676; Kovačević-Kojić 1970: 115; Id. 2007: 433.

67 Kovačević-Kojić 1970: 115; Dinić 2003b: 524-525; Spremić 1994: 439, 511, 571, 592, 594, 619-620, 627, $630,654,725$.

68 Spremić 1994: 114, 284, 259-260, 291, 353, 407, 463, 602, 608, 615-616, 619, 622, 681, 718; KovačevićKojić 1970: 115.

69 Dinić-Knežević 1985: 13-14; Manken 1960: 210-211; Kovačević-Kojić 1970: 115; Spremić 1994: 593, 613, 684.

70 Kovačević-Kojić 1970: 115; Manken 1960: 156; Spremić 1994: 260, 424-427, 432, 635, 709, 711; Dinić 2003b: 630, 665-667.

1 Manken 1960: 343; Kovačević-Kojić 1970: 271.

72 Dinić-Knežević 1982: 256; Manken 1960: 392; Spremić 1994: 679, 711, 730.

3 Spremić 1994: 628, 641, 677; Dinić-Knežević 1982: 256.

74 Kovačević-Kojić 1970: 103-111.

75 Hrabak 1979: 175-207; Id. 1984a: 21-32; Popović 1970: 143-148; Zirojević 1970: 197-200; Bojanić 1974: 19, 35, 40, 53, 83; Evlija Čelebija 1979: 313-314. 


\section{Traded Goods}

\subsection{Silver}

Dubrovnik's merchants were the main actors in the exchange of goods between the Dubrovnik Littoral and the lower Sava and Danube regions, and thus had a wide range of goods in circulation. It is well-known that silver was the medieval Serbian state's most important export. Even though the silver mines were rather far from the cities on the Sava and the Danube, and the roads connecting them to Dubrovnik did not pass through these cities, there is some surviving data related to the silver trade there. However, the data is limited and does not seem to indicate there was intensive silver trade in the area. ${ }^{76}$

The silver trade is mentioned somewhat more often in Smederevo. A well-known trader, Benko Kortuljević, received silver from his partner, Vuk Bobaljević (Babailo), who lived in Smederevo. ${ }^{77}$ Therefore, it is important to mention that some of Dubrovnik's merchants from Smederevo had connections to Novo Brdo, Srebrenica, and Rudnik, which may suggest silver was among the goods they traded. ${ }^{78}$ It is also known that Alviz Rastić's (Resti) silver, which had been sent from the Despot's capital to Venice in 1455, was plundered at Bosanska Krupa. Some amount of silver also went to Hungary. When granting privileges to the city of Pressburg, King Sigismund had anticipated silver imports from Serbia. These goods undoubtedly passed through some of the cities on the border, most likely Belgrade or Smederevo. Dubrovnik's merchants also imported silver to Dubrovnik from Hungary. ${ }^{79}$ Wills left by Dubrovnik's merchants in Smederevo mention several times that they owned silver. ${ }^{80}$ Damjan Đurđević (Georgio) also traded in silver. ${ }^{81}$ In any case, the mint located in the capital produced coins with the largest circulation in the Desptoate, so this precious metal had to be brought there in large quantities. ${ }^{82}$ Copper was also traded, which most likely came from Rudnik due to the many merchants from Smederevo who were also based there. Copper was exported in large quantities from Hungary. Some of this copper was transported along the Danube and then further down the Sava to Gradiška, from which the road led to Senj. ${ }^{83}$ There is also some data on the lead trade. ${ }^{84}$

76 Hrabak 1980: 62-63; Dinić-Knežević 1986: 16, 60, 65; Ćirković 1969: 65; Wenzel 1876: 650-651; Kalić 1967: 295-296; Dinić 2003b: 545-546, 561; Dinić 1958: 14-15, 25-26, 28-29, 64 72; Stojanović 1934: $11-$ 21, 30-32; Spremić 1994: 627-628, 630-631; Kalić 1970: 58.

77 Despot Đurađ's charter for Srebrenica from 1445 forbade the Dubrovnik's merchants from trading this metal in Smederevo. This measure probably did not apply to all of Dubrovnik's traders because it was not included in the general charter. The goal may have been to exclude the traders from other cities from purchasing it in Smederevo. The Dubrovnik merchants did not oppose this ban. In any case, there is some data on the silver trade in Smederevo. (Stojanović 1934: 11-21, 30-32; Spremić 1994: 627-628, 630-631).

78 Some of them were Franko Vasiljević, who was mentioned in Smederevo and Rudišta, and Nikola Radulinović, who was mentioned in Smederevo and Srebrenica. (Kovačević-Kojić 1970: 110; Hrabak 1984b: 29-51).

9 Hrabak 1980: 62.

80 Kovačević-Kojić 1970:112.

81 Spremić 1994: 638.

82 Dimitrijević 1970: 71-86.

83 Hrabak 1985a; 43-50; Ćirković 1969: 65.

84 Ćirković 1970: 84; Hrabak 2003: 357. 


\subsection{Salt}

Another important trade item was salt. The most important salt mines in Hungary were in Transylvania, and from there it was transported to Szeged, an important center for further salt distribution, via the Mures River. There were salt chambers in Mitrovica, Kovin, Slankamen, and Sonta, ${ }^{85}$ and salt was also imported to Serbia from Hungary. ${ }^{86}$ Later on, Franko Vasiljević was responsible for its sale in Belgrade. He held a lease on royal salt revenues and, along with his partners, traded in Priština and Smederevo. ${ }^{87}$

\subsection{Fine Cloth}

The largest commercial activity, however, was the cloth trade. Many kinds of foreign cloth were sold. Dubrovnik's merchants sold Italian, French, and Byzantine cloth in the hinterland, and some of them also ended up in the cities on the Sava and Danube. There was trade in cloth as early as the end of the thirteenth century. A dispute was recorded in Dubrovnik in October 1296, regarding a piece of Saint Hilaire broadcloth sold in Srem for eight perpers. ${ }^{88}$ Martin Menčetić (Mence) also sent cloth to Mitrovica in 1335 via his partner, Nikola Herpa (Cherpa). Paske Ščeze, who also traded in Mitrovica, stated in his will, written in 1348, that he owned 40 lengths of fustian. A partnership formed by Georgije Pucić (Poca) and Berlinger from Barcelona was also involved in the cloth trade. On the square in Mitrovica, in 1369, the Ban of Macsó and Rozsdi Mihaly accepted five lengths of cloth from two men from Dubrovnik in exchange for a debt owned by one of their fellow citizens. ${ }^{89}$ Pavle Gundulić (Gondola) also sent cloth to Hungary, and he and his partners received a shipment of it in 1395. Gundulić (Gondola) was in Venice, where he procured fabrics, in 1398 and bought 32 lengths of broadcloth. At that time, Martol Crijević (Zrieva) also bought 63 lengths of broadcloth. We know they worked closely and had connections in Hungary and Mitrovica. ${ }^{90}$ In a letter to Despot Stefan, Dubrovnik's merchants wrote that they were bringing pure silk, velvet, velvet embroidered with gold circles, gold brocade, silk and cotton damask, silk linings, and pearls to larger towns and to the Despot's court in Belgrade, where there were many wealthy people who could afford such expensive fabrics. ${ }^{91}$ Nikola Gučetić (Goce) also took cloth to Hungary. ${ }^{92}$

After the restoration of the Despotate, Dubrovnik's merchants sent large quantities of cloth to Smederevo. At that time, it was a gathering place for nobles and the wealthy for whom such expensive clothing was befitting. Starting in October 1444, cloth trading

85 Kubinyi 1988: 213-214; Szilágyi 2012: 90. In the Golden Bull of 1222, King Andrew II of Hungary decreed that the only places where salt could be distributed were Szeged, Salacea, and at the border. (Fejer 1829: 377; Rokai 1983: 141, 160, 165).

86 Jireček 1915: 39.

87 Dinić 1958: 81-84; Kalić 1967: 302; Id. 1970: 58.

8 Dinić-Knežević 1982: 35; Čremošnik 1932: 164-165.

Dinić-Knežević 1986: 15-16, 63.

Dinić-Knežević 1982: 80, 83; Id. 1986: 67-68.

Kalić 1967: 89; Stojanović 1934: 220.

Dinić-Knežević 1982: 257. 
partnerships began to be formed in Serbia that would last for single journey, for several months, or for a year. Smederevo is mentioned several times as a place where sales were made. The most commonly traded cloth was broadcloth from Dubrovnik, but imported broadcloth was also traded.

In February 1445, a partnership of two Dubrovnik residents received ten lengths of fine cloth worth 310 ducats to be taken to Smederevo. In 1451, Marin Cidilović, was tasked with selling just over thirty ells of golden brocade in Smederevo on behalf of Ivan Obradović valued at around 133 ducats. Two years later, he sent six pieces of Florentine broadcloth to the Despot's capital.

In 1455, Matija Ilijin and Matija Smoljanović formed a partnership in which they invested 2,100 ducats. Matija Ilijin first traveled to the March of Ancona carrying kermes (a type of red dye) and other goods, which he sold there. He then bought 66 lengths of broadcloth worth 1,700 ducats and invested the rest of the money in wool and other goods. The broadcloth Matija Smoljanović purchased was brought to Serbia to be sold. It seems Smoljanić remained in Serbia for quite some time, because in November of the following year, Matija Ilijin sent him another 42 lengths of broadcloth. Their partnership lasted until March 1459, so he may have remained there even longer. These fabrics most certainly went to the Serbian court and the most important nobles because they were the ones who dressed in fine imported fabrics. ${ }^{93}$

Rusko Pribisalić had a shop in Smederevo where he sold fabrics and ribbons, and Milorad Radosalić's Smederevo shop stocked, among other things, 30 pieces of broadcloth that were 50 ells in length, which he had brought from Dubrovnik. Damjan Đurđević (Georgio) and members of the Sorkočević (Sorgo) family also traded in fabrics. ${ }^{94}$ In the summer of 1452, Voivoda Jakša imported fabrics duty-free from Dubrovnik, which he had purchased for Despot Đurađ's noblemen. ${ }^{95}$ Andrija Sorkočević's (Sorgo) servant Petar was transporting four pieces of Milanese fustian, among other things, when he was attacked by brigands in 1454 on the way from Rudišta to Valjevo. ${ }^{96}$ The cloth trade was so lucrative and widespread that from 1427 to 1459 around 15 to 20 percent of trading partnerships operating in Serbia only traded in fabrics. It seems that a good amount of this merchandise went to the capital because this city is most often mentioned as a place where goods were sold. ${ }^{97}$

Regarding fabrics, the Dubrovnik merchants were particularly interested in the export of the kermes. They exported large quantities of it to Florence, Ferrara, Venice, Ancona, and Pesaro, but some of it remained in Dubrovnik for their own manufacturing industry. The brothers Benko and Miho Kotruljević sourced kermes in Smederevo. In a 1438 inventory of everything they had traded until then, kermes valued at 1282 ducats and 37 grossi was listed along with other goods. They had traded in kermes even before compiling the inventory, and this amount indicates they had been trading on a broad scale. One of the brothers lived in

93 In February 1445, 7 lengths of broadcloth and 10 lengths of fine fabrics were sent to Smederevo, 13 lengths of cloth in September 1450, and 30 and a half lengths of brocade in June 1451,. In September 1459, cloth worth 610 ducats was sent to Smederevo (Dinić-Knežević 1982: 253-255). 
Smederevo and sent goods from there. A kermes order sent to Florence in 1438 weighed 1280 libras. In 1443, containers of kermes weighing 220 libars were shipped from Smederevo to Dubrovnik. One of the Dubrovnik merchants in Smederevo who traded in kermes was Matko Ilić. In the 1450s, the most well-known importer of kermes in Italy was Marin Cidilović, who had strong connections with Smederevo as well as Florence and Venice. He had a partner in Smederevo to whom he sent people transporting kermes and who collected his payments for him. In the autumn of 1453, Radič Bogdanović committed to sending 1400 libras of kermes to Cidilović, who had requested 2000 libras, if possible. Damjan Đurđević (Georgio) also traded in kermes. A goldsmith, Maroje Marković, who had come to Smederevo, also traded in kermes. Several documents attest to the extensive kermes trade in Smederevo. ${ }^{98}$

\subsection{Other goods}

Dubrovnik merchants also traded in a variety of other goods such as jewelry, weapons, and vessels. ${ }^{99}$ There are a lot of data from the Ottoman period on the export of large quantities of cow skin from Belgrade and Smederevo, which were then sent to Italy. ${ }^{100}$ Fish products were also exported after being preserved in a variety of ways including salt or aspic or drying them in the sun, all of which made them easier to transport over long distances because they did not easily spoil. ${ }^{101}$ Beeswax and honey were also common trade goods for merchants from Dubrovnik. ${ }^{102}$

In conclusion, the merchants of Dubrovnik were the main economic link between the Dubrovnik Littoral and the cities on the southern Hungarian border-primarily Mitrovica, Ilok, Kovin, Belgrade, and Smederevo. Starting in the fourteenth century, they played a key role in the development of this trade route, and most trade was brokered by them. They supplied the cities on the Sava and the Danube with various goods, but they mostly brought cloth. This was especially apparent during the Despotate, when Belgrade and Smederevo were developed cities and where the wealthy nobility gathered and dressed in the fine fabrics brought by the merchants of Dubrovnik.

Over a long period of time, Dubrovnik's merchants took on a leading role in trade in this area, but the expanding war that gripped the Sava and Danube regions with the arrival of the Ottomans was often detrimental to them. Because of this, integrative processes were often disrupted, and as a result commerce never reached the level it did in Western Europe. But nevertheless, it served as an important framework for the development of the regions along the Hungarian and Serbian borders. The considerable experience Dubrovnik's merchants invested in trade and politics in the Balkans strengthened Dubrovnik, known as the 'City at the Foot of Mt. St. Srđ', and they continued to engage in trade and serve as

\footnotetext{
Hrabak 2010: 276-288; Radojčić 1967: 30-31; Spremić 1994: 638.

Dinić 1958: 54, 58, 65; Dinić-Knežević 1986: 15, 61, 67-68, 187.

100 Hrabak 1985b: 86, 90-93.

101 Engel 2001: 56; Hrabak 1960: 59-66.

102 Dinić-Knežević 1986: 16; Manken 1960: 368; Magdics 1888: 5; Spremić 1994: 638; Thallóczy, Áldásy 1907: 306-307; Hrabak 1985b: 87, 96; Bojanić 1974: 21-22, 35.
} 
intermediaries even after Serbia (1459) and Hungary (1526-1541) fell and during the period of the Ottoman Empire's greatest expansion. The lower Danube and Sava regions would continue to engage in the Ottoman economic and commercial systems until the Treaty of Karlowitz and the expansion of the Habsburg Monarchy, which built new trade routes on the foundations of the old connections and integrated Central and Southeast Europe.

\section{REFERENCES:}

Bojanić, D. Turski zakoni i zakonski propisi iz 15. i 16. veka za smederevsku, kruševačku i vidinsku oblast, Beograd: Istorijski institut, 1974.

Božić, I. 'Ekonomski i društveni razvitak Dubrovnika u 14-15 veku', Istorijski glasnik,1,1949, 2661. (Serbian Cyrillic)

Codex diplomaticus Regni Croatiae, Dalmatiae et Slavoniae, no: 13, a. 1360-1366, ed. Tadija Smičiklas et al. Zagreb: JAZU, 1915.

Codex diplomaticus Regni Croatiae, Dalmatiae et Slavoniae, no: 15, a. 1374-1378, ed. Tadija Smičiklas, Marko Kostrenčić, Zagreb, JAZU, 1934.

Čelebi, E. Putopis, odlomci o jugoslovenskim zemljama, prevod: H. Šabanović, Sarajevo: Veselin Masleša,1979.

Čremošnik, G. 'Acta cancellariae et noteriae annorum 1278-1301', Monumenta historca archivi Ragusini, series tertia, fasc. 1, Beograd: Srpska kraljevska akademija, 1932.

Ćirković, S. 'Civitas Sancti Demetrii', u: R. Prica (ur.), Sremska Mitrovica - u čast dvadesetpetogodišnjice oslobođenja grada, Sremska Mitrovica 1969, 59-71. (Serbian Cyrillic) 'Dubrovnik i zaleđe u srednjem veku', u: V. Đokić (ur.), Rabotnici, vojnici, duhovnici, Beograd: Equilibrium, 1997, 47-55. (Serbian Cyrillic)

. 'Kretanja prema severu', u: J. Kalić (ur.), Istorija srpskog naroda II, Beograd: Srpska književna zadruga, 1994, 314-329. (Serbian Cyrillic)

. 'Prilozi za istoriju Kovina u srednjem veku', Zbornik Matice srpske za istoriju, 1, 1970, 8386. (Serbian Cyrillic)

. 'Smederevo-prestonica srpske Despotovine', u: V. Čubrilović (ur.), Oslobođenje gradova u Srbiji od Turaka 1862-1867, Beograd: Srpska akademija nauka i umetnosti, 1970, 61-69. (Serbian Cyrillic)

Ćuk, R. 'Kolonije u srpskim srednjevekovnim gradovima', u: J. Kalić (ur.), Socijalna struktura srpskih gradskih naselja 12-18. vek, Smederevo: Muzej u Smederevu-Beograd: Odeljenje za istoriju Filozofskog fakulteta, 1992. (Serbian Cyrillic)

Dimitrijević, S. 'Novac grada Smedereva', u: V. Čubrilović (ur.), Oslobođenje gradova u Srbiji od Turaka 1862-1867, Beograd: Srpska akademija nauka i umetnosti, 1970,71-86. (Serbian Cyrillic)

Dinić, M. 'Acta consiliorum Republicae Ragusinae I', Zbornik za istoriju, jezik i književnost srpskog naroda, 15, Beograd: Srpska akademija nauka, treće odeljenje, 1951.

. 'Acta consiliorum Republicae Ragusinae II', Zbornik za istoriju, jezik i književnost srpskog naroda, 21, Beograd: Srpska akademija nauka, treće odeljenje 1964.

. 'Documenta res Belgradi mediae aetatis illustrantia II', Monumenta historiam Belgradi spectantia, Beograd: Istorijski arhiv Beograda, 1958.

. 'Dubrovčani kao feudalci u Srbiji i Bosni', u: S. Ćirković, V. Đokić (ur). Iz srpske istorije srenjeg veka, Beograd: Equilibrium, 2003a, 419-430 (Serbian Cyrillic)

'Trepča u srednjem veku', u: S. Ćirković, V. Đokić (ur). Iz srpske istorije srenjeg veka, 
Beograd: Equilibrium, 2003c, 669-678. (Serbian Cyrillic)

. 'Za istoriju rudarstva u srednjevekovnoj Srbiji i Bosni I-II', u: S. Ćirković, V. Đokić (ur). Iz

srpske istorije srenjeg veka, Beograd: Equilibrium, 2003b, 455-668. (Serbian Cyrillic)

Dinić-Knežević, D. 'Dubrovački arhiv kao izvor za istoriju Vojvodine', Arhivist, 1-2, 1979.

. 'Dubrovčani u službi ugarskih vladra tokom srednjeg veka', Zbornik Matice srpske za

istoriju, 31, 1985. (Serbian Cyrillic)

. 'Slovenski živalj u urbanim naseljima srednjevekovne Južne Ugarske', Zbornik Matice srpske za istoriju, 37, 1988, 7-42. (Serbian Cyrillic)

. Dubrovnik i Ugarska u srednjem veku, Novi Sad: Filozofski fakultet, 1986. (Serbian Cyrillic)

. Tkanine u privredi srednjovekovnog Dubrovnika, Beograd: Srpska akademija nauka i umetnosti, 1982. (Serbian Cyrillic)

Engel, P. The realm of St. Stephen, A history of medieval Hungary, ed. Andrew Ayton, London-New

York: I.B. Tauris Publishers, 2001.

Fejér, G. Codex diplomaticus Hungariae ecclestiasticus ac civilis, III/1, Budae 1829.

Gelcich, J. 'Monumenta Ragusina, libri reformationum, T. 4, A. 1364-1396', Monumenta spectantia historiam Slavorum Meridionalium, 28, Zagrabiae: Academia scientiarum et artium Slavorum Meridionalium, 1896.

. 'Monumenta Ragusina, libri reformationum, T. 5, A. 1301-1336', Monumenta spectantia historiam Slavorum Meridionalium, 29, Zagrabiae: Academia scientiarum et artium Slavorum Meridionalium, 1897.

Hrabak, B. 'Izvoz bakra iz Ugarske i susednih krajeva preko Senja u 14. i 15. veku', Zbornik Matice srpske za istoriju, 31, 1985a, 43-50. (Serbian Cyrillic)

. 'Trg Valjevo u srednjem veku', Istorijski glasnik, 3-4, 1953, 91-102. (Serbian Cyrillic)

. 'Crvac iz Bosne i Srbije (15-17. vek)', u: B. Hrabak (ur.), Iz Starije prošlosti Bosne $i$

Hercegovine 7, Beograd: Arhivar, 2010. (Serbian Cyrillic)

. 'Dubrovačke naseobine i poslovne stanice u Ugarskoj do 1526. godine', u: S. Gavrilović

(ur.), Balkan i Panonija kroz istoriju, Novi Sad: Filozofski fakultet, 2006, 99-114.

. 'Dubrovački privrednici u Smederevu u doba Osmanlija', Anali zavoda za povjesne znanosti istraživačkog centra JAZU u Dubrovniku, 17, 1979, 165-214.

. 'Dubrovački trgovci u Beogradu pod Turcima', Godišnjak grada Beograda, 13, 1966, 29

47. (Serbian Cyrillic)

. 'Dubrovački trgovci u osmanlijskom delu Panonije do 1570. godine', Zbornik Matice srpske za istoriju, 30, 1984a, 7-42. (Serbian Cyrillic)

. 'Dubrovčani u Ugarskoj i njihove veze sa Beogradom i Srbijom', Godišnjak grada Beograda,

27, 1980, 57-70. (Serbian Cyrillic)

. 'Hercegovački ponosnici', u: B. Hrabak (ur.) Iz Starije prošlosti Bosne i Hercegovine II,

Beograd: Arhivar, 2003. (Serbian Cyrillic)

. 'Putnici iz hrišćanske Evrope o privrednim prilikama slovenskih zemalja na Balkanu pod

Turcima u 16. veku', Zbornik Filozofskog fakulteta u Prištini, 6, 1969, 1-45.

. 'Ribolov i riblja pijaca u Beogradu u 16. i 17. veku', Godišnjak grada Beograda, 7, 1960,

58-66. (Serbian Cyrillic)

. 'Rudnik pod Šturcem i njegova dubrovačka naseobina', Zbornik radova narodnog muzeja

Čačak, 15, 1984b, 5-86. (Serbian Cyrillic)

- 'Sirovine Podunavlja u trgovini Dubrovčana iz Beograda 1521-1640', Godišnjak grada

Beograda, 32, 1985b, 85-100. (Serbian Cyrillic)

Ivánfi, E. 'Keve vármegye eméleke', Századok, 5, 1872.

Jireček, K, Radonić, J. Istorija Srba II, Beograd: Slovo Ljubve, 1981. (Serbian Cyrillic)

. 'Trgovački putevi i rudnici Srbije i Bosne u srednjem veku', u: M. Dinić (ur.), Zbornik 
Konstantina Jirečeka 1, Beograd: Naučno delo, 1959. (Serbian Cyrillic)

. Važnost Dubrovnika u trgovačkoj povjesti srednjeg veka, Dubrovnik: Dubrovačka hrvatska tiskara, 1915.

Kalić, J. 'Beograd u međunarodnoj trgovini srednjeg veka', u: V. Čubrilović (ur.), Oslobođenje gradova u Srbiji od Turaka 1862-1867, Beograd: Srpska akademija nauka i umetnosti, 1970, 47-60 (Serbian Cyrillic)

'Beogradska povelja despota Stefana Lazarevića', u: S. Ćirković, K. Čavoški (ur.), Srednjovekovno pravo u Srba u ogledalu istorijskih izvora, Beograd: Srpska akademija nauka i umetnosti, 2009. (Serbian Cyrillic)

Kalić-Mijušković, J. Beograd u srednjem veku, Beograd: Srpska književna zadruga, 1967. (Serbian Cyrillic)

Kisić, M, Božanić, S. 'Odgovor dubrovačkog veća na pismo kralja Žigmunda od 9. XI 1427 - prevod i jezička analiza', Istraživanja, 23, 2012. (Serbian Cyrillic)

Kolarević, A. 'Talovec- posjed i grad', Istorijski glasnik, 1-2, 1975. (Serbian Cyrillic)

Konstantin Filozof. 'Život despota Stefana Lazarevića', u: Stare srpske biografije 15. i 17. veka, prevod: L. Mirković, Beograd: Srpska književna zadruga, 1936. (Serbian Cyrillic)

Kovačević-Kojić, D. 'O domaćim trgovcima u srednjevekovnoj Srebrenici', in: Gradski život u Srbiji i Bosni 14-15. vijek, ed. Tibor Živković, Beograd: Istorijski institut, 2007, 429-438. (Serbian Cyrillic)

. 'Dubrovačka naseobina u Smederevu', u: V. Čubrilović (ur.), Oslobođenje gradova u Srbiji od Turaka 1862-1867, Beograd: Srpska akademija nauka i umetnosti, 1970, 103-120. (Serbian Cyrillic)

Krekić, B. 'Prilog istoriji mletačko-balkanske trgovine druge polovine 14. veka', Godišnjak Filozofskog fakulteta u Novom Sadu, 2, 1957. (Serbian Cyrillic)

. 'Vuk Bobaljević', Zbornik radova Vizantološkog instituta, 4, 1956, 115-140. (Serbian Cyrillic)

Kubinyi, A. 'Königliches Salzmonopol und die Städte des Königreich Ungarn in Mittelalter', in: Wilhelm Rausch (ed.), Stadt und Salz, Linz 1988.

. 'Urbanisation in the east-central part in medieval Hungary', in: L. Gerevich (ed.), Towns in medieval Hungary, Budapest: Akademiai Kiado, 1990, 103-151.

Lučić, J. 'Povijest Dubrovnika od XI stoljeća do 1205. godine', Anali historijskog odjela centra za znanstveni rad JAZU u Dubrovniku,13-14, Dubrovnik 1976.

Ludaić, M. 'Različita stara pisma koja se Srba tiču', Srbski letopis, 36/1, Pešta 1862. (Serbian Cyrillic)

Magdics, I. Ráczkevei Okmánytár, Székesfehérvár, 1888.

Manken, I. Dubrovački patricijat u 14. veku, Beograd: Naučno delo, 1960. (Serbian Cyrillic)

Medini, M. Dubrovnik Gučetića, Beograd: Naučna knjiga, 1953. (Serbian Cyrillic)

Miljković-Bojanić, E. Smederevski sandžak 1476-1560 - zemlja-naselja-stanovništvo, Beograd: Istorijski institut-Službeni glasnik, 2004. (Serbian Cyrillic)

Mladenović, A. Povelje i pisma despota Stefana: tekst, komentari, snimci, Beograd: Čigoja štampa, 2007, (Serbian Cyrillic)

Nagy, I. Hazai Okmánytár. Codex diplomaticus patrius VII, Budapest 1880.

Novaković, S. Zakonski spomenici srpskih država srednjeg veka, ed. Rade Mihaljčić, Beograd 2005. (Serbian Cyrillic)

Popović, T. 'Dubrovačka kolonija u Smederevu od 1459. godine do kraja 16. veka', u: V. Čubrilović (ur.), Oslobođenje gradova u Srbiji od Turaka 1862-1867, Beograd: Srpska akademija nauka i umetnosti, 1970, 143-148. (Serbian Cyrillic)

Rački, F. 'Monumenta Ragusina, libri reformationum, T. 2, A. 1347-1352,1356-1360 additamentum a. 1301-1305, 1318, 1325-1336', Monumenta spectantia historiam Slavorum Meridionalium, 
vol. 13, Zagrabiae: Academia scientiarum et artium Slavorum Meridionalium, 1882.

Radojčić, S. 'Crvac', Zograf, 2, Beograd 1967. (Serbian Cyrillic)

Radonić, J. Zapadna Evropa i balkanski narodi prema Turcima u prvoj polovini 15. veka, Novi Sad: Matica srpska, 1905. (Serbian Cyrillic)

Rokai, P. "Brodovi” na Dunavu i pritokama na području južne Ugarske i srednjem veku', u: V. Čubrilović (ur.), Plovidba na Dunavu i njegovim pritokama kroz vekove, Beograd: SANU, 1983, 139-176. (Serbian Cyrillic)

. 'Poslednje godine balkanske politike kralja Žigmunda', Godišnjak Filozofskog fakulteta u Novom Sadu, 12/1, 1969, 89-109.

. Dubrovnik i Ankonitanska marka u srednjem veku, Novi Sad: Filozofski fakultet, 1995.

Ruvarac, I. 'Prilozi za povest srpskog naroda u zemlji ugarskoj', u: N. Radojčić (ur.), Zbornik Ilariona Ruvarca, Beograd: Srpska kraljevska akademija, 1934. (Serbian Cyrillic)

Spremić, M. 'Dubrovačka trgovačka društva u Despotovini Đurđa Brankovića', u: M. Spremić (ur.), Prekinut uspon, Beograd: Zavod za udžbenike i nastavna sredstva, 2005, (Serbian Cyrillic)

. Despot Đurađ Branković i njegovo doba, Beograd: Srpska književna zadruga, 1994. (Serbian Cyrillic)

Stojanović, Lj. Stare srpske povelje i pisma 1/2, Beograd, 1934. (Serbian Cyrillic)

Szilágyi, M. Arpád period communication networks, road systems in Western Transdanubia, (phd thesis manuscript), Budapest: CEU, 2012.

Tadić, J. 'Istorija Dubrovnika do polovine 15. veka', Istorijski časopis,18, 1971, 13-44. (Serbian Cyrillic)

. 'Litterae et commissiones Ragusinae I', Fontes rerum Slavorum meridionalium, Beograd: Srpska kraljevska akademija, 1935.

. 'Privreda Dubrovnika i srpske zemlje u prvoj polovini 15. veka', Zbornik Filozofskog Fakulteta u Beogradu, 10/1, 1968, 519-538 (Serbian Cyrillic)

Teleki, J. Hunyadiak kora Magyarországon X, Pest, 1853.

Thallóczy, A. Áldásy, A. Magyarorság és Szerbia közti összeköttetásek oklevéltára 1198-1526, Budapest 1907.

Tkalčić, I. 'Monumenta Ragusina, libri reformationum, T. 1, A. 1306-1347', Monumenta spectantia historiam Slavorum Meridionalium, vol. 10, Zagrabiae: Academia scientiarum et artium Slavorum Meridionalium, 1879.

Tričković, R. 'Beograd pod turskom vlašću 1521-1804', Zbornik za orijentalne studije SANU, 1, 1992. (Serbian Cyrillic)

Vasin, D. 'Trgovina Dubrovčana u mitrovici u 14. veku', Spomenica Istorijskog arhiva Srem, 16, 2017, 13-29. (Serbian Cyrillic)

Vitković, G. Prošlost, ustanova i spomenici ugarskih «kraljevh šajkaša» od 1000. do 1872, Beograd: Štamparija Kraljevine Srbije, 1887. (Serbian Cyrillic)

Wenzel, G. Diplomacziai emlékek az Anjou-korból III, Budapest, 1876.

Zirojević, O. 'Smederevo od pada pod tursku vlast do kraja 16. veka', u: V. Čubrilović (ur.), Oslobođenje gradova u Srbiji od Turaka 1862-1867, Beograd: Srpska akademija nauka i umetnosti, 1970, 193-200. (Serbian Cyrillic) 


\author{
ДЕЈАНА ВАСИТ \\ Универзитет у Источном Сарајеву, Филозофски факултет Пале
}

\title{
СНЕЖАНА БОЖАНИТ
}

Универзитет у Новом Саду, Филозофски факултет

\section{СРЕДЊОВЕКОВНИ ЧОВЕК НА РЕЛАЦИЈИ ПРИМОРЈЕ - ГРАДОВИ НА ЈУЖНОЈ ГРАНИЦИ УГАРСКЕ, ТРГОВИНА КАО ФАКТОР КРЕТАҢА}

\begin{abstract}
Резиме
Важну улогу у развоју транзитне трговине на Балкану, али и шире, су имали становници Дубровника. Доба највећег интензитета дубровачке трговине пада у период од XIII до XV века, у доба када је у српској држави цветало рударство, привредна грана која је у великој мери повезала ова два друштва и омогућила им узајамну корист. Градови у Посавини и Подунављу су такође били у домену дубровачког пословања, те се захваљујући њиховој делатности и на овим просторима развила интензивна трговина. Они су и ту оснивали колоније у складу са својим потребама. Најпре су се настанили у Митровици, затим у Ковину и Београду, а потом и у Смедереву. Било их је у другим местима као што је Илок. На овим просторима су били присутни већ од XIII века. У трговини која се обављала на овој релацији учествовали су чланови познатих властеоских породица Растић, Петрања, Рањина, Менчетић, Кашица, Пуцић, Гучетић, Соркочевић, Гундулић, Лукаревић, Бунић, Катена, Бобаљевић, Цријевић, Ђорђић, Градић као и многи пучани.

Главну спону у привредном смислу између градова на јужној граници Угарске, пре свега Митровице, Илока, Ковина, Београда и Смедерева и Приморја, су чинили дубровачки трговци. Они су од XIV века били кључан фактор за развој трговине на овој релацији, те се њиховим посредством обављао највећи део трговине. Снабдевали су градове на Сави и Дунаву разном робом, али су највише доносили тканине. То је посебно уочљиво у доба постојања Деспотовине, када су Београд и Смедерево били развијени градови, те се у њима окупљало богато племство које се облачило у фине тканине које су Дубровчани доносили. Дубровачки трговци су у дугом периоду имали доминантну улогу у размени на овим просторима, а на штету им је врло често ишао ратни вихор који је захватао Посавину и Подунавље доласком Турака. Из тог разлога интегративни процеси често су нарушавани и због тога степен трговачке размене није био на нивоу западноевропског, али свакако је представљао важан оквир за развитак пограничних области Угарске и Србије.

Велико искуство које су Дубровчани уносили у своје трговачке и политичке послове на Балкану давало је снагу Граду под Светим Срђем да и после пада Србије (1459) и Угарске (1526$1541)$, настави да игра трговачку и посредничку улогу и у периоду највеће експанзије Османлија. Посавина и Подунавље наставиће да живе у Османском систему трговачких и привредних веза, све до Карловачког мира и експанзије Хабзбуршке монархије која ће на темељима старих веза изгради нове путеве трговине и интеграције Централне и Југоисточне Европе.
\end{abstract}

Кључне речи: Дубровачки трговци. трговина, подручје Саве и Дунава, тканине, средњи век. 